\title{
NATURAL AND CULTURAL HERITAGE OF UKRAINE: EXPERIENCE OF THEMATIC STUDY AND ATLAS ELECTRONIC MAPPING
}

\author{
Kateryna POLYVACH
}

Institute of Geography of the National Academy of Sciences of Ukraine, Ukraine

kateryna.polyvach@gmail.com

\begin{abstract}
The article considers the main methodological approaches to the thematic study of natural and cultural heritage $(\mathrm{NCH})$ and the results of their implementation in the electronic atlas "Population of Ukraine and its natural and cultural heritage". The structure and content of the two thematic blocks of the Atlas in the composition of 37 maps is built in such a way as to cover all the variety of definitions that characterize the spheres of nature and culture heritage in Ukraine. Based on the developed methodological approaches, for the first time in Ukraine, cultural and landscape zoning of the country's territory at the macro level was performed, in the taxonomic system of which 14 cultural and landscape regions and 52 cultural and landscape macroregions were identified. For the purposes of mapping natural heritage, a no official definition of this term has been developed, the typology of objects has been determined, a database of existing and promising objects and territories with their coordinate reference has been formed, and several relevant maps have been created. The problem of a huge number of potential objects of cultural heritage mapping (over 100 thousand) in the process of forming the data base was solved by not considering necropolis historical monuments, most commemorative plaques, and some minor buildings in the complexes of monuments and by reflection, mainly monuments of national (partially, local) significance. The Atlas has significantly expanded the composition of functional categories of cultural heritage by integrating a wide range of cultural and natural, tangible and intangible, movable and immovable heritage by separate research areas. The result of this work are maps of ethnocultural, religious, scientific, and technical heritage. These are the first in Ukraine specialized maps of similar topics and scope, which constitute the scientific novelty of the Atlas, allow to significantly expand the subject field of research $\mathrm{NCH}$, and can contribute to the introduction into scientific practice of new categories of heritage. For the first time in Ukraine, based on collected, systematized, thorough and comprehensive information, a holistic picture of the country's NCH is shown.
\end{abstract}

Key words: cultural heritage, natural heritage, electronic atlas, mapping.

DOI: https://doi.org/10.17721/2413-7154/2021.86.53-66

UDC: $504(477)$

Received: October 04, 2021.

Revised: November 18, 2021.

Accepted: November 23, 2021.

\section{ПРИРОДНА ТА КУЛЬТУРНА СПАДЩИНА УКРАЇНИ: ДОСВІД ТЕМАТИЧНОГО ВИВЧЕННЯ ТА АТЛАСНОГО ЕЛЕКТРОННОГО КАРТОГРАФУВАННЯ}

\section{Катерина ПОЛИВАЧ}

Інститут географії Національної академії наук України, Україна

kateryna.polyvach@gmail.com

\begin{abstract}
Анотація: У статті розглянуто основні методичні підходи до тематичного вивчення природної та культурної спадщини (ПіКС) та результати їх впровадження у електронному Атласі «Населення України та його природна і культурна спадщина». Структура і зміст двох тематичних блоків Атласу ПіКС у складі 37 карт побудована таким чином, щоб охопити все розмаїття понять, що характеризують природно-заповідну та пам'яткоохоронну сфери України. На засадах розроблених методичних підходів вперше в Україні виконано культурно-ландшафтне районування території країни на макрорівні, в таксономічній системі якого виділено 14 культурно-ландшафтних країв та 52 культурно-ландшафтних макрорайонів. Для цілей картографування природної спадщини була розроблена відсутня дотепер офіційна дефініція цього терміну, визначено типологію об'єктів, сформовано базу даних з існуючих та перспективних до заповідання об'єктів та територій з їх координатною прив'язкою та створено декілька відповідних карт. Проблема величезної кількісті потенційних об'єктів картографування культурної спадщини (понад 100 тис.) в процесі формування інформаційної бази вирішувалась за рахунок неврахування некрополістичних пам'яток історії, більшості пам'ятних знаків та окремих другорядних споруд у складі комплексів пам'яток та шляхом відображення, головним чином, пам'яток національного (частково, місцевого) значення. В Атласі ПіКС суттєво розширено склад функціональних категорій культурної спадщини шляхом інтегрування широкого спектру об'єктів культурної і природної, матеріальної і нематеріальної, рухомої і нерухомої спадщини за окремими дослідницькими областями. Результатом цієї роботи стали карти етнокультурної, релігійної і науково-технічної спадщини. Ці перші в Україні спеціалізовані карти подібної тематики та масштабу охоплення, які становлять наукову новизну Атласу, дозволяють значно розширити предметне поле досліджень ПіКС та можуть сприяти введенню у наукову практику нових категорій спадщини. Вперше в Україні на основі зібраної, систематизованої та наочно представленої ґрунтовної та всебічної інформації показана цілісна картина ПіКС країни.
\end{abstract}

Ключові слова: природна спадщина, культурна спадщина, електронний атлас, картографування. 
Постановка проблеми. Прийняття у вересні 2015 р. світовими лідерами на Генеральній Асамблеї $\mathrm{OOH}$ «Порядку денного у сфері сталого розвитку на період до 2030 року», було ознаменовано однією 3 найзначніших новацій: усвідомлюючи цінності культурного різноманіття і внеску культури в сталий розвиток, культурний компонент було вперше включено до більшості «Цілей сталого розвитку» та активізацію зусиль $з$ охорони та збереження світової культурної та природної спадщини виділено в окреме завдання.

Незамінним інструментом людства у справі збереження культурних цінностей світу провідними міжнародними установами визнано культурне картографування, яке включає в себе широкий спектр методів і видів діяльності - від збору та управління даними до складного картування 3 використанням геоінформаційних систем. Зокрема, використання картографування культур ЮНЕСКО розглядає в якості фундаментального кроку в досягненні мети збереження культурного розмаїття в світі (UNESCO, 1972).

Як важливий науково-методичний засіб із унікальними можливостями в контексті реалізації цих цілей виступають географічні атласні твори та, 3 недавніх пір, атласні геоінформаційні системи.

Послідовно здійснюючи роботу 3 розвитку національної інфраструктури геопросторових даних, відділ картографії Інституту географії НАН України у 2020 р. завершив багаторічне розроблення тематичного електронного атласу «Населення України та його природна і культурна спадщина» (далі - Атлас ПіКС). Вперше в Україні на основі зібраної, систематизованої та наочно представленої грунтовної та всебічної інформації показана цілісна картина природної та культурної спадщини країни (далі - ПіКС).

Висвітлення основних результатів розроблення Атласу ПіКС щодо загальних наукових та методичних засад, структури, змісту розділів та деяких карт, функціональності та особливостей технологічних процесів його створення тощо зроблено в колективній монографії його авторів (Rudenko, 2021), однак нагальною потребою $\epsilon$ подальша деталізація проведених робіт за окремими складовими Атласу.

Метою дослідження є викладення основних концептуальних та методичних підходів до тематичного вивчення природної та культурної спадщини та результатів їх впровадження у електронному атласі «Населення України та його природна і культурна спадщина».

Аналіз попередніх публікацій та досліджень. Картографування природної i культурної спадщини як новий напрям тематичної картографії та на засадах неподільності, взаємозумовленості та рівноцінності об'єктів культури та природи почало формуватися 3 кінця XX ст. При чому картографування природних територій особливої охорони, які зазвичай складають основне ядро природної спадщини, має давню історію та є достатньо розробленою предметною областю. Зокрема, в колишньому СРСР $370-$ х років XX ст. карти охорони природи з відображенням заповідних об'єктів і територій, ареалів рідкісних видів рослин і тварин тощо неодмінно включали в комплексні географічні атласи або в атласи охорони природи.

Картографування культурної спадщини започатковано порівняно недавно. Загалом в останні роки обидва напрями отримали значний поштовх у своєму розвитку в країнах пострадянського простору, Свропи та Північної Америки.

Наприклад, у томі 2. «Природа. Екологія» Національного атласу Росії тему природної спадщини відтворюють карти природних територій особливої охорони міжнародного й федерального, регіонального та місцевого значення, ключових орнітологічних територій міжнародного значення, особливо цінних водно-болотних угідь. У томі 4 «сторія. Культура» підрозділ про культурну спадщину є найбільшим за обсягом і включає 24 дрібномасштабні карти різних сюжетів стосовно країни загалом та і1і суб'єктів зокрема. Національний атлас Росії був виданий в поліграфічній та електронній версіях, останній варіант атласу розміщений в мережі Інтернет (http://национальныйатлас.pф.)

Тенденція переходу від створення класичних картографічних творів відповідної тематики до розроблення інтерактивних засобів відображення каталогізованої інформації, яка обумовлена широким впровадженням ГІС, що дозволяє забезпечити інтерактивну взаємодію користувача 3 картографованою інформацією, спостерігається у світі 3 початку XXI ст. Важливим кроком вперед стало переведення цих засобів в он-лайн режим, варіювання рівня доступу користувача до інформації в залежності від мети їі використання, проведення масштабування i переміщення по полю карти за допомогою вбудованої програми - візуалізатора тощо.

Прикладами засобів візуалізації інформації про природну спадщину у Північній Америці є інтерактивні карти природної спадщини провінції Онтаріо (Канада, 2014), штату Нью-Йорк (США, 2008) та штату Вірджинія (США, 2013).

В Свропі такий досвід накопичено у зв'язку із зобов'язаннями країн щодо виконання Директиви INSPIRE, спрямованої на створення інфраструктури просторових даних Свропейського Союзу. Наприклад, Агентство природи Шотландії, яке до 2020 року було відоме як Шотландський фонд природної спадщини, свого часу ініціювало розроблення та підтримку інтерактивної карти природної спадщини Шотландії та публікує набір відповідних просторових даних (https://www.nature. scot/). Теж саме стосовно пам'яток архітектури та інших визначних місць культурної спадщини

(c) Катерина Поливач 
здійснює агентство «Історична Шотландія» на своєму сайті (http://www.historic-scotland.gov.uk/) i на інтерактивній карті «Pastmap» (https://pastmap. org.uk/map).

Аналогічний підхід з публікацією національного набору даних щодо об'єктів культурної спадщини та їх візуалізацією на інтерактивній карті можна спостерігати у Бельгії (https://www.onroerenderfgoed. be), Нідерландах (https://www.monumenten.nl/ monumenten/kaart), Польщі (https://mapy.zabytek.gov. pl/nid/), Франції (http://atlas.patrimoines.culture.fr/atlas/ trunk/) та інших країнах Свропи.

У 2012 році до 40-річчя Конвенції про охорону всесвітньої культурної і природної спадщини (далі - Конвенції ВКПС) було опубліковано Атлас всесвітньої спадщини, що став першим всеосяжним картографічним джерелом 3 докладними картами, фотографіями та інформацією про природні та культурні об'єкти, включені до Списку всесвітньої спадщини ЮНЕСКО (De Agostini, 2012). На відміну від цього атласу, який зафіксував стан Списку на певну дату, на сайті Центру всесвітньої спадщини розміщена та постійно оновлюється інтерактивна карта його об'єктів (https://whc.unesco.org/en/ interactive-map/).

В Україні також накопичено певний досвід традиційного та електронного картографування ПіКС, в тому числі, атласного. Карти охорони природи та культурної спадщини, є характерною ознакою атласного комплексного та тематичного картографування окремих регіонів та країни в цілому протягом останніх десятиріч, однак загальнодержавного спеціалізованого картографічного твору, який комплексно показав і1і сучасний стан не було розроблено.

Початкові пропозиції щодо картографування ПіКС в Україні та його перспективних напрямків, в тому числі, шляхом створення тематичного атласу «Україна. Культурна та природна спадщина», були викладені автором цієї статті (Polyvach, 2005), а уведення до вступного блоку Національного атласу України (Polyvach, 2007) декількох авторських карт пам'яток ПіКС, історико-культурних заповідників та історичних населених місць України стало першим практичним кроком на шляху до започаткування та розвитку цього напряму тематичного картографування.

В подальших дослідженнях автора здійснювалось доопрацювання проекту концепції Атласу, його структури та орієнтовного змісту карт на традиційних засадах його виготовлення. (Polyvach, 2012).В той же час, швидкий розвиток геоінформаційних, мультимедійних та інтерактивних технологій із застосуванням потужних технічних засобів створили широкий спектр нових можливостей для атласного картографування та, як наслідок, змінили світові та вітчизняні концептуальні підходи до шляхів виготовлення та використання географічних атласів - від традиційних до електронних, та далі - до атласних інформаційних систем, для яких характерні модульність та безперервність розвитку, еволюційність і динамічність, сумісність, мультимасштабність, мультимедійність та універсальність.

Ці тенденції знайшли своє відображення у введенні до наукової тематики Інституту географії НАНУ теми із розроблення атласу «Населення України та його природна i культурна спадщина» та поставленого завдання щодо його створення як комплексного електронного картографічного твору науково-довідкового характеру, нове покоління яких відрізняється проблемною орієнтацією, багаторівневістю картографування, множиною взаємопов'язаних і взаємодоповнюючих форм реалізації.

Практичним полігоном для опрацювання методичних підходів до створення Атласу стала підготовка друкованої та електронної форм атласудовідника «Природно-заповідний фонд Київської області», яку здійснив Інститут географії на замовлення Департаменту екології та природних ресурсів Київської обласної державної адміністрації у 2015 році (Polyvach, 2016).

Наступним важливим етапом стало розроблення структурних та технологічних засад розбудови атласної інформаційної системи культурної спадщини України (АІСКС), яке здійснювалось за підтримки проекту Українського культурного фонду у 2018 році. В монографії, підготовленої за результатами проекту, АІСКС визначено, як проблемно-орієнтовану інформаційну систему, що створюється як програмно-технологічний i інструментальний засіб для вирішення завдань зі збору, зберігання, оброблення, аналізу та представлення інформації про наявність, охорону, збереження та використання об'єктів та територій культурної спадщини, умови i середовище їх існування на заданих просторових рівнях 3 розширеними можливостями геовізуалізаціi, просторово-статистичного аналізу та підтримки прийняття відповідних управлінських рішень (Polyvach, 2018).

При цьому, як підготовчу та першочергову стадію на шляху до повномасштабної АIC та як ядро мультимедійної системи, в підтвердження думки Б. Рістедта (Rystedt, 1995), можна розглядати саме створення електронного Атласу ПіКС.

Істотним організаційним чинником сприяння розробленню Атласу ПіКС на якісному науковому та інформаційному рівні стало його включення до одного 3 напрямів співробітництва між Міністерством культури України та Національною академією наук України відповідно з Меморандумом, підписаним 27 червня 2018 року.

Виклад основних результатів дослідження. Структура і зміст тематичного блоку «Природна i культурна спадщина» Атласу побудована таким чином, щоб охопити все розмаїття понять, що характеризують природно-заповідну та пам'яткоохоронну сфери України. До складу блоку увійшло 28 карт 3 різноманітними сюжетами, об’єднаних у декілька структурних складових (Рис. 1). 
Блок відкривається розділом «Місце України в природній і культурній спадщині світу та Європи», який містить серію карт, що презентують визначні культурні та природні пам'ятки України, насамперед, об'єктів і територій світового значення, занесених до Списку всесвітньої спадщини ЮНЕСКО та кандидатів до занесення.

Виготовлено також карти 3 нанесенням найвизначніших історико-культурних пам'яток («Сім чудес України») та найвизначніших природних пам'яток («Сім природних чудес України») за результатами відповідних Всеукраїнських громадських акцій, які були проведені у 20072008 роках. Попри громадський характер акцій визнання правомірності отриманих результатів підтверджується тим фактом, що більшість їх переможців та фіналістів внесені або є номінантами для внесення до Списку всесвітньої спадщини ЮНЕСКО.

Завершуватиме розділ карта «Культурноландшафтне районування Украӥни» (КЛР), розроблення якого в Україні здійснено вперше. КЛР серед різноманітних методів районування, розроблених в географічних дисциплінах, вважається багатьма дослідниками найбільш адекватним по відношенню до культурної та природної спадщини та $€$ «основоположною процедурою при плануванні управлінських дій щодо культурних ландшафтів» (Vedenin \& Kuleshova, 2004).

Загальною метою КЛР було виявлення, виділення і розмежування цілісних природнокультурних системних територіальних утворень різного рівня, як сукупностей взаємопов'язаних культурних ландшафтів, які взаємодіють на певній території. Джерельно-інформаційною базою проведення КЛР слугували дослідження, що відображають територіальну диференціацію України за багатьма групами ознак та мають розроблені відповідні схеми районування 3 їх картографічним втіленням, а саме 3 : фізико-географічного районування (О. Маринич, Г.Пархоменко, О.Петренко, П.Шищенко), ландшафтного (П.Шищенко), геоботанічного (Т. Андрієнко, Г.Білик, Є.Брадіс та ін., Я.Дідух, Ю. Шеляг-Сосонко), гідрографічного (В.Гребінь та ін.), природно-сільськогосподарського (А. Мартин, С. Осипчук, О. Чумаченко), історикоетнографічного (М. Глушко, Р. Кирчів, О. Косміна, С. Макарчук), фольклористичного (Р. Кирчів), лінгвістичного (Українська мова: Енциклопедія), історичного (Я. Верменич, В. Горбик, П. Скрипник, $\Phi$. Заставний, О.Маринич), етногеографічного та етнолого-географічного (М. Дністрянський, Я. Жупанський, В. Круль), географо-топонімічного (Т. Купач) та ін.

В результаті, в таксономічній системі КЛР країни виділено 14 культурно-ландшафтних країв (Поліський, Чернігово-Сіверський, Волинський, Карпатський, Подільський, Київський, Полтавський, Слобожанський, Донецький, Придніпровський, Побузький, Нижньодніпровський, Приазовський, Причорноморський) та 52 культурно-ландшафтних макрорайонів.

Розроблення розділу карт «Природна спадщина Украӥни» мало певні труднощі, оскільки в Україні, на відміну від міжнародного права, термін «природна спадщина» не набув відповідного відображення в законодавчому полі, відповідно відсутня однозначна дефініція, не розроблено усталеної типології об’єктів тощо.

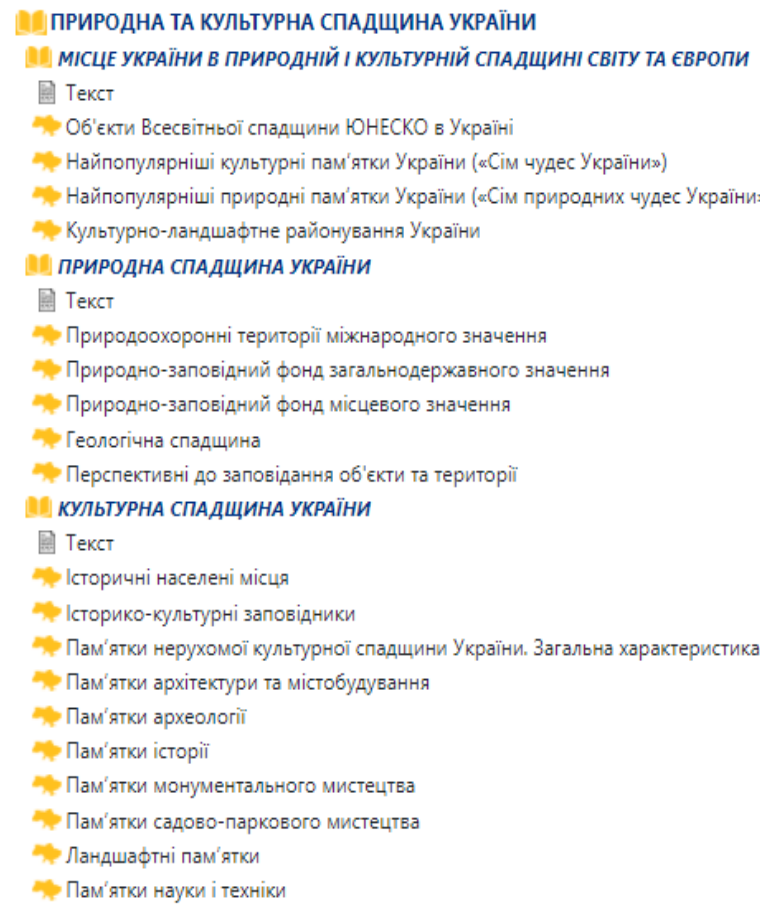

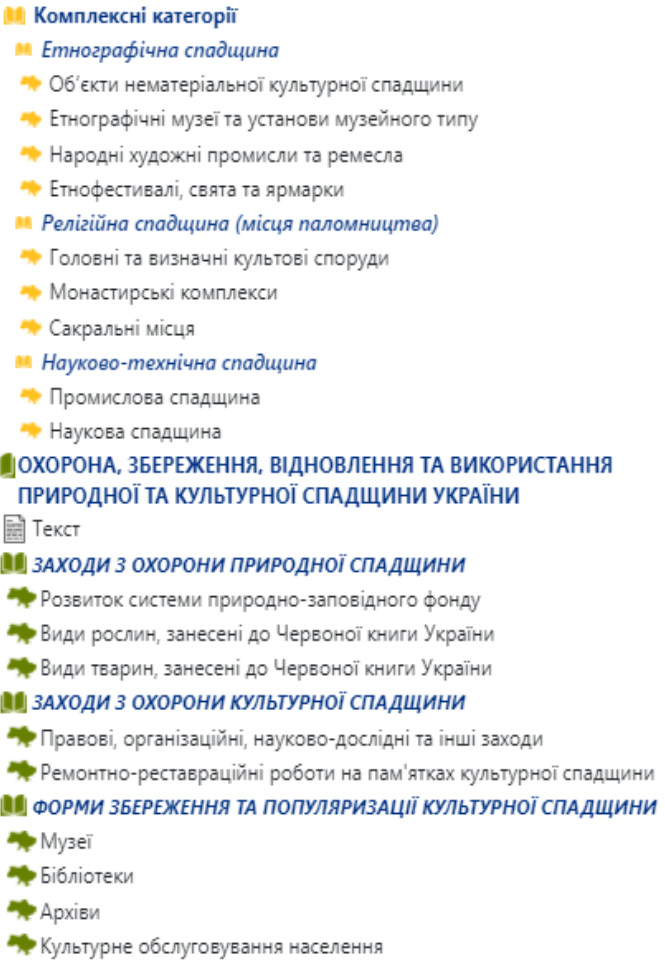

Рис. 1. Природна і культурна спадщина у структурі інтерактивного електронного атласу «Населення України та його природна і культурна спадщина» 
Спираючись на результати попередньо проведених досліджень, при розробленні Атласу прийнято, що під природною спадщиною України мається на увазі сукупність унікальних, рідкісних, зникаючих чи типових об’єктів (територій, акваторій) i явищ середовища природного або природноантропогенного походження, що мають особливу екологічну, наукову, інформаційну, пізнавальноосвітню, оздоровчу, рекреаційну та естетичну цінність, охоплені існуючими та перспективними правовими формами та механізмами особливої охорони на міжнародному, національному, регіональному та місцевому рівнях або потребують їх застосування (Rudenko \& Polyvach, 2015).

Відповідно з цим розділ включає: карту «Природоохоронні територіі міжнародного значення». Території цієї категорії, незважаючи на відсутність і1ї закріплення в національному законодавстві, створюються на виконання підписаних Україною міжнародних конвенцій та включають: об'єкти та номінанти до Списку Всесвітньої спадщини ЮНЕСКО згідно з Конвенцією ВКПС; водно-болотні угіддя міжнародного значення (об'єкти та номінанти для внесення до «Рамсарського Списку водно-болотних угідь міжнародного значення»); об'єкти Світової мережі біосферних резерватів ЮНЕСКО; території особливого природоохоронного значення (ТОПЗ) об'єкти та номінанти для внесення до Смарагдової мережі Європи, яка формується в рамках «Бернської конвенції про охорону дикої флори і фауни та природних середовищ їх існування в Європі» на території країн, які не є членами Свропейського Союзу. Зокрема, станом на 04.12.2019 до Смарагдової мережі включено 377 українських територій загальною площею понад 7 млн га (за даними Council of Europe, 2019).

- карти «Природно-заповідний фонд загальнодержавного значення» та «Природнозаповідний фонд місиевого значення». Центральне місце в системі територій та об'єктів особливої правової охорони посідає природно-заповідний фонд України (ПЗФ), який за результатами даних обліку (станом на 01.01.2020) мав в своєму складі 8512 територій та об'єктів загальною площею 4,4 млн га в межах території України.

Проведений аналіз веб-ресурсів, а також розроблених картографічних творів, засвідчив про відсутність на центральному та на більшості регіональних офіційних природоохоронних вебсайтах комплексної довідкової та картографічної інформації про стан та перспективи розвитку ПЗФ. Суттєвим недоліком існуючих ресурсів є повільне поновлення наведених даних (або відсутність взагалі), що викликає необхідність їх актуалізації у зв'язку зі зростанням кількості та розмірів територій та об'єктів.

Тому, в ході розроблення карт розділу на основі матеріалів Міністерства захисту довкілля та природних ресурсів України (проектів створення, положень, картосхем тощо) була сформована база даних об'єктів та територій ПЗФ загальнодержав- ного та місцевого значення за категоріями природні заповідники, біосферні заповідники, національні природні парки, регіональні ландшафтні парки, заказники, пам'ятки природи, заповідні урочища) та штучно створені об'єкти (ботанічні сади, дендрологічні парки, зоологічні парки, парки-пам'ятки садово-паркового мистецтва. Подальша систематизація даних була пов'язана 3 їх координатною прив'язкою (в умовах відсутності, в багатьох випадках, картографічної інформації, яка посилилася внаслідок труднощів при визначенні меж значних за розміром територіальних об'єктів), детальним описом тощо 3 наступною вивіркою правильності атрибутивних даних 3 Державного кадастру територій та об'єктів ПЗФ України.

- карту «Геологічна спадщзина». Цей термін широко використовують в геологічній науці та 3 нею ототожнюють «пам'ятки природи і будь-які інші природоохоронні об'єкти, геологічна цінність яких $\epsilon$ переважаючою і визначальною» (Wimbledon et al., 1999). Карту, що візуалізує просторове поширення геологічних пам'яток України, до яких віднесені найбільш характерні відслонення гірських порід i форми земної поверхні, які мають наукову та естетичну цінність, створено за даними 4-х томного видання «Геологічні пам'ятки України» (Kalinin \& Gurskiy, 2006-2011). Інформацію про більш ніж 600 об'єктів геокодовано та структуровано за видами пам'яток та їх приуроченістю до тих чи інших геоструктурних елементів.

- карту «Перспективні до заповідання об'єкти та території», яка відображає потенційні ділянки і території перспективного заповідання та правової охорони, базу даних щодо яких у межах рівнинної України 3 узагальне-ними напрацюваннями за усіма природними зонами, було розроблено на основі НДР «Розробка наукових принципів та ландшафтно-біотичних критеріїв організації перспективної сітки заповідних територій різного рангу», що виконувалась Інститутом географії у 2015-2019 роках із залученням експертів та матеріалів інших академічних установ, матеріалів Міністерства захисту довкілля та природних ресурсів України тощо.

Отримання на основі карт розділу достовірної, обробленої та наочно представленої інформації про стан ПЗФ уможливить базове забезпечення відповідних установ актуальними просторовими даними для ефективного управління розвитком природоохоронних територій на різних рівнях та стане підтримкою у прийнятті управлінських рішень, проведенні в установах ПЗФ наукових досліджень, сприятиме розвитку екологічно орієнтованих видів туризму, інформуванню громадян та популяризації екоосвітніх знань тощо. Важливу роль відіграватиме можливість надання наукової, методичної та інформаційної підтримки для територіального аналізу даних і перспективного планування та підвищення їх ефективності при складанні науково обгрунтованих прогнозів розвитку ПЗФ та формуванні програм сталого 
(збалансованого) розвитку країни та її територій.

Розділ «Культурна спадщиина України» - один із найбільших в Атласі, розкриває багато тем і містить значну кількість карт, представлених у підрозділах, що характеризують нерухому культурну спадщину та кілька інтегральних категорій, які об'єднують у своєму складі різні види матеріальної (рухомої і нерухомої) та нематеріальної культурної спадщини.

Для цілей розроблення карт цього розділу було прийнято відмінне від законодавчо прийнятого авторське визначення культурної спадщини як сукупності унікальних успадкованих від попередніх поколінь матеріальних та нематеріальних культурних цінностей, пам'яток та історико-культурних територій і об'єктів, що мають виняткове історичне значення для збереження і розвитку самобутності України і всіх їі етнічних та соціальних спільнот, їхнього внеску до світової цивілізації та формування культурного простору.

До підрозділу «Нерухома культурна спадшцина» включені карти особливих історикокультурних територій («Історичні населені місця» та «Історико-культурні заповідники»), як результат територіального підходу до збереження, охорони та використання культурної спадщини, при якому спадщина зберігається в ㄲï традиційному природному та історико-культурному середовищі.

Розроблення карт за видами пам'яток культурної спадщини та їх типами було пов'язане 3 наступними картографо-інформаційними труднощами. В Україні відсутня повна офіційна інформаційна картина щодо обсягів та стану пам'яток (об’єктів) культурної спадщини, що перебувають на державному обліку. Їх кількість, за даними державної статистичної звітності, становила на початок 2019 р. 127,6 тис. нерухомих об'єктів культурної спадщини, в тому числі: археології - 65520, історії - 44853, монументального мистецтва - 2259, архітектури та містобудування - 14524, садово-паркового мистецтва - 326, ландшафтних - 4, науки i техніки - 122 (без урахування тимчасово окупованих територій Автономної Республіки Крим, Донецької й Луганської областей). 3 метою обліку об'єктів матеріальної та духовної культури виняткової історичної, художньої, наукової чи іншої культурної цінності запроваджено Державний реєстр нерухомих пам'яток України (2000), наповнення та ведення якого виконується вкрай повільно - станом на 2021 р. до нього включено менше 10\% від їх загальної кількості.

Лише завдяки зусиллям науковців та громадськості в українському сегменті «Вікіпедії» в рамках фотоконкурсу «Вікі любить пам'ятки» (англ. Wiki Loves Monuments), що проводиться в Україні 32012 р., була створена і постійно поповнюється єдина публічна база даних культурної спадщини України, яка структурована згідно офіційній класифікації та налічує на початок 2021 p. 91,9 тис. об'єктів, що є найбільшим за обсягом і інформативним за змістом ресурсом в Україні. Записи цього реєстру інтегровані в міжнародну базу та містять назву об'єкта, адресу розташування, охоронний номер і дату рішення про взяття на облік, вид і категорію, для 72,7 тис. об'єктів реєстр містить адресу, 23,8 тис. - точну географічну довготу і широту, для 37,8 тис. фотографії та 5,5 тис. - стислий опис (за даними Wikimedia Commons, 2021).

Наявність величезної кількісті потенційних об'єктів картографування значно ускладнило процес формування інформаційної бази даних та доповнення сформованих переліків пам'яток (об'єктів) спадщини даними щодо просторової локалізації об'єктів картографування, візуалізації топографічного розташування та необхідної атрибутивної (описової) інформації.

Постало питання про встановлення такого обсягу об'єктів, який мав би забезпечити повноцінне та цілісне уявлення про культурну спадщину України та врахувати потребу у створенні зручних можливостей для користування Атласом в інтернеті або на електронних носіях.

Вирішення цієї проблеми здійснювалось наступним шляхом. Як відзначають пам'яткознавці, недостатня розробленість науково-концептуальних засад виявлення й обліку пам'яток призвела до парадоксальних показників складу нерухомих об’єктів культурної спадщини України: майже 80\% пам'яток історії присвячені подіям Другої світової війни, а 3 точки зору їхньої типології понад 30 тис. пам'яток складають поховання (Gavrilyuk et al., 2011).

Іншою проблемою $є$ наявність у складі пам'яток історії великої кількості пам'ятних знаків (меморіальних дошок, стел, скульптур, обелісків, пам'ятних каменів, надгробків тощо, присвячених видатним історичним та державним діячам, діячам науки, культури i мистецтва або встановлених для увічнення пам'ятних та історичних подій). Тому, пам'яткознавцями пропонується чітке відокремлення у понятійно-термінологічному плані та виділення двох паралельно існуючих груп об'єктів: a) нерухомих пам'яток історії, б) пам'ятних знаків (Fedorova, 2015).

Виходячи $з$ цих та інших пропозицій, створення інформаційної бази Атласу здійснювалось без врахування некрополістичних пам'яток історії, більшості пам'ятних знаків та окремих другорядних споруд (господарських, житлових, виробничих тощо) у складі комплексів (ансамблів) пам'яток архітектури, містобудування, історії.

До інших важливих особливостей картографування нерухомої культурної спадщини в Атласі слід віднести відображення, головним чином, пам'яток національного (та, частково, місцевого) значення, при чому археологічна спадщина в Атласі теж представлена лише пам'ятками національного значення та подається в масштабі населеного пункту без точного геокодування.

В результаті були розроблені карти за видами пам'яток та їх типами, а саме: «Пам'ятки архітектури та містобудування» (об'єкти культової архітектури; житлової архітектури; фортифікаційні 
споруди; адміністративно-громадської архітектури; промислової архітектури; містобудування; садовопаркового і ландшафтного мистецтва); «Пам'ятки археологї̈ (стоянки та поселення; поховальні об'єкти; оборонні споруди; пам'ятки давніх культів; пам'ятки мистецтва та епіграфіки; пам'ятки, пов'язані 3 виробництвом); «Пам'ятки історії» (державного устрою та суспільного життя; соціальних та національно-визвольних рухів; історії виробництва і техніки; розвитку науки, освіти, мистецтва та спорту; воєнної історіі); «Пам’ятки монументального мистецтвв» (монументальна скульптура; монументальний живопис; монументальнодекоративне мистецтво); «Пам'ятки садово-паркового мистецтва» «Ландшафтні пам'ятки»; «Пам'ятки науки $i$ техніки» (промислові споруди; інженерні споруди; науково-виробничі об'єкти).

Загальна характеристика кількості пам'яток культурної спадщини в розрізі регіонів містить показники їх кількості та розподілу за видами; щільність розподілу усіх пам'яток в розрахунку на 1 кв. км території використано в якості фону карт.

В Атласі суттєво розширено склад функціональних груп об'єктів культурної спадщини, як це здійснюється в ряді ініціатив та програм ЮНЕСКО, ICOMOS та інших міжнародних організацій.

Результатом проведеної дослідницької та відповідної інформаційної роботи 3 інтегрування широкого спектру об'єктів культурної і природної, матеріальної і нематеріальної, рухомої і нерухомої спадщини за окремими дослідницькими областями та їх наступного картографування, стали карти етнокультурної, релігійної і науково-технічної спадщини. Зазначені терміни, як окрема категорія, не мають офіційного визначення у міжнародних документах та вітчизняному пам'яткоохоронному законодавстві, однак зустрічаються в деяких нормативно-правових актах, науковій літературі або діловій документації.

Представлені в Атласі перші в Україні спеціалізовані карти подібної тематики та масштабу охоплення, можуть не тільки сприяти введенню у наукову практику цих категорій, вони дозволяють значно розширити предметне поле досліджень культурної та природної спадщини.

Розробленню карт підрозділу «Етнокультурна спадщина» передував аналіз сучасних підходів до вивчення та встановлення ролі i місця етнокультурної спадщини в загальній системі культурної спадщини, збереження якої є однією 3 найактуальніших проблем сьогодення для багатьох країн світу. Термін «етнокультурна спадщина», як окрема категорія не має офіційного визначення у міжнародних документах та вітчизняному пам'яткоохоронному законодавстві, але часто зустрічається в ряді нормативноправових актів, науковій літературі або діловій документації, оскільки дозволяє чітко виокремити цей аспект культурної спадщини та означити предмет дослідження.

В Атласі було запропоновано вважати етнокультурну спадщину сукупністю культурних цінностей, об'єктів та елементів культурної спадщини у їх взаємозв'язку та взаємозалежності 3 природною спадщиною, яка являє собою культурний здобуток та спадок певного етносу, джерело етнокультурної інформації для збереження, популяризації, освоєння та передачі від покоління до покоління.

Цим самим етнокультурна спадщина визнається як багаторівнева та багатокомпонентна система, що є органічною та невід'ємною складовою матеріальної і нематеріальної культурної спадщини та природної спадщини. Картографування етнокультурної спадщини має на меті відобразити геопросторові закономірності iٓ формування та сучасний стан, як результат етнокультурних процесів, що відбуваються на території країни.

Підрозділ «Етнокультурна спадщина» складається 3 чотирьох багаторівневих та високоінформативних карт: «Нематеріальна культурна спадщина», «Етнографічні музеї та установи музейного типу», «Народні художні ремесла i промисли», «Етнофестивалі, свята та ярмарки».

Джерелом інформації для наповнення карти «Нематеріальна культурна спадцина» стали списки елементів нематеріальної культурної спадщини - ЮНЕСКО, Національний та обласні (регіональні). Внесені (або номіновані для внесення) до переліків елементи та місця їх сучасного побутування розподілені за трьома категоріями та об'єднані за наступними видами: усні традиції та форми вираження, виконавське мистецтво; звичаї, обряди, святкування; традиційні ремесла.

Вагому роль у збереженні етнокультурної спадщини відіграють музеї, що склало основну тему карти «Етнографічні музеї та установи музейного muny». Вплив сучасних трансформаційних процесів призвів до суттєвого перетворення призначення музею від інституції, що зберігає та експонує переважно матеріальні рухомі предмети, до включення в його цільові функції також процесів музеєфікації, зберігання, популяризації, актуалізації та освоєння елементів нематеріальної культури та природних територій, які мають історичну цінність.

До музейної складової етнокультурної спадщини включені: етнографічні музеї - заповідники; музеї етнографії, побуту, народних ремесел та декоративноприкладного мистецтва; середовищні музеї, 3 них: музеї народної архітектури та побуту просто неба; музеї-хати (садиби); заклади музейного типу (етнографічні та історико-культурні комплекси).

Карта "Народні художні ремесла і промисли» присвячена, як зазначається в ряді урядових документів, одній з найважливіших традиційних галузей української культури, яка сприяє збереженню національної ідентичності, $є$ консолідуючим фактором у процесі формування нації, а також важливою складовою економічного розвитку держави. Народні художні промисли були і залишаються візитівкою України, основою іiі автентичності та самобутності, а їхні вироби - затребуваним продуктом як на внутрішньому, так і на зовнішньому ринках.

В умовах відсутності об’єктивної і актуальної 
статистичної інформації щодо поточного стану народних художніх промислів в Україні (кількість майстрів, обсяг реалізованої продукції, ринки збуту, картографування мистецьких осередків тощо), основною джерельною базою для наповнення карти слугували дані Інституту мистецтвознавства, фольклористики та етнології ім. М.Т.Рильського НАН України про традиційні центри (осередки) народних художніх промислів, як існуючі, так i зниклі, у XX-XXI ст. (Skrypnyk, 2011).

Оріснтовне уявлення про сучасний стан народних художніх промислів в Україні було отримано під час мапування понад 120 місць сучасного побутування традиційних ремесел, як елементу нематеріальної культурної спадщини, що внесені (або номіновані) до Репрезентативного списку ЮНЕСКО, національного та обласних (регіональних) переліків, та відображені на карті «Нематеріальна культурна спадщина».

Центри промислів були розподілені на види за наступними групами виробів: художня вишивка; художне ткацтво, килимарство, ліжникарство; художня кераміка, гончарство; художня обробка металу, каменю; художня обробка дерева (різьблення); художнє плетіння з рослинних матеріалів (лоза, солома, рогоза); декоративний розпис, писанкарство.

Важливу роль в популяризації етнокультурної спадщини України відіграють найрізноманітніші етнофестивалі, свята та ярмарки, кількість та територіальне поширення яких постійно зростає, тому закономірно, що цьому сюжету присвячена окрема карта.

3 урахуванням існуючих класифікацій в науковій літературі (Topornytska, 2015) та для цілей відображення фестивалів в електронному атласі їх запропоновано поділити за наступними видами згідно 3 головною метою їх проведення, що включає саме етнокультурну складову: фольклорно-етнографічні; 3 нагоди релігійних свят та обрядового дійства; традиційних промислів та ремесел; традиційних страв та напоїв; національних культур; ярмаркиетнофестивалі.

За значенням (статусом) фестивалів виділені міжнародні; національні та всеукраїнські; обласні (регіональні), районні та міські. Основною інформаційною джерельною базою наповнення карти стали інтернет-ресурси.

Виділення такої категорії як «Релігійна спадщина», що $є$ темою наступної карти, було обумовлено багатьма чинниками. Так, за даними Центру всесвітньої спадщини, об’єкти, що мають релігійний чи духовний характер, $є$ найбільшою тематичною категорією у Списку всесвітньої спадщини та становлять приблизно 20\% від їх загальної кількості.

ЮНЕСКО, відповідно до рішення Комітету всесвітньої спадщини та після Київської заяви про захист релігійних цінностей у рамках Конвенції ВКПС у 2010 р., постанови Генеральної асамблеї IКОМОС про охорону та покращення об'єктів сакральної спадщини, будівель та ландшафтів у 2011 р. та інших документів, висунула Ініціативу щодо спадщини, що представляє релігійний інтерес (UNESCO, 2020).

Україна $\epsilon$ державою 3 багатою історією i великою кількістю конфесій, тому на їі території розміщені святині багатьох релігій. Інтерес до релігійних центрів весь час зростає, адже це місця активного паломництва, які $\epsilon$ також пам'ятками історії й архітектури та зберігають у найбільш цілісному вигляді історичні та природні ландшафти. Невипадково, що більшість об'єктів від України у Списку всесвітньої спадщини також має релігійний характер. Це Собор Святої Софії з прилеглими монастирськими спорудами та Києво-Печерська лавра в Києві, ансамбль історичного центру м.Львів зі всесвітньо відомими Архикатедральним собором святого великомученика Юрія та Катедральним собором Успіння Пресвятої Богородиці, резиденція митрополитів Буковини і Далмації у Чернівцях, 8 дерев'яних церков Карпатського регіону України. Кандидатами на внесення до списку визнані Борисоглібський i Спасо-Преображенський собори у Чернігові та Кирилівська і Андріївська церкви у Києві.

За даними Мінкультури України станом на 01.01.2020 p. 4046 культових будівель мали статус пам'ятки архітектури або 21,9\% їх загальної кількості.

Один 3 найбільш інформативних туристичних сайтів України - Турпортал «IGotoWorld» (https:// ua.igotoworld.com/ua/), виділив понад 1,9 тис. найбільш популярних об'єктів релігійної спадщини, питома вага яких складає 26,6\% із загальної кількості усіх позначених 7,2 тис. туристичних об'єктів.

Питання, дотичні до вивчення, систематизації, охорони, використання та популяризації релігійної (культової,сакральної)спадщини Україниєпредметом дослідження представників багатьох дисциплін, зокрема, географії релігії, паломництва, релігійного туризму (Л.Атаман, Т.Божук, Ю.Городиський, Т.Гринчишин, Т.Завадовський, Д. Каднічанський, Л. Ключко, А. Ковальчук, Ю. Когатько, І. Костащук, О. Кучабський, О. Любіцева, А. Манько, К. Мезенцев, С. Павлов, В.Патійчук, С. Романчук, М.Рутинський, Л.Шевчук), сакральної архітектури (В. Вечерський, О. Кравченко, О.Лесик, І. Могитич, Л.Прибєга, В.Слободян), іконопису (Д.Степовик), церковного пам'яткознавства (Н. Сенченко, О. Шуба) та інших.

В той же час, досвід картографування релігійної спадщини (Ю.Городиський, Т.Гринчишин, I. Костащук, В.Пересадько, О.Шпурік) має недостатньо велику історію та практичний доробок, щоб оформити його в окремий напрямок тематичного картографування.

Виходячи із розробленого в роботі авторського визначення релігійної спадщини як сукупності матеріальних і нематеріальних культурних цінностей та пам'яток - культових споруд, творів мистецтва, реліквій (святинь) різних конфесій, сакральних місць та ландшафтів, місць здійснення релігійних ритуалів (обрядів), традицій, які мають історичну, архітектурну, естетичну або мистецьку унікальність, 
було визначено складові елементи їі структури та створено геоінформаційну базу даних найбільш важливих відомостей, що стосуються пам'яток національного та, частково, місцевого значення. Зрозуміло, що вона не містить вичерпний перелік всіх пам'яток, місць чи цінностей релігійної спадщини, оскільки в даному випадку являє собою інструмент для картографування 3 метою популяризації найбільш значущих пам'яток України та її регіонів.

В результаті, до складу підрозділу увійшло три багаторівневі та високоінформативні карти:

- «Головні та визначні культові споруди», що відображає собори (кафедральні храми та головні церкви монастирів) та церкви різних конфесій;

- «Монастирські комплекси», більшість 3 яких - не тільки видатні пам'ятки культової архітектури, це місце збереження національних та релігійних святинь, традицій та звичаїв тощо. Чудотворні ікони, цінні книги, мощі святих, інші святі речі, чудотворні джерела на їх території з давнини привертають до них паломників з звідусіль;

- «Сакральні місця», що відображає місця поховання святих (праведників) та видатних релігійних діячів різних конфесій та сакральні місця: джерела, скелі, гори, долини, печери та печерні храми.

Джерельною базою розроблення цих карт слугували регіональні переліки об'єктів культурної спадщини, інформаційні та картографічні матеріали з Інтернет-джерел:

- контенти офіційних сайтів Православної церкви України (https://www.pomisna.info/ $\mathrm{uk} /)$, Української православної церкви (МП) (http://orthodox.org.ua), Української грекокатолицької церкви (http://news.ugcc.ua/ua/), зокрема, Інтерактивна карта УГКЦ (https://map.ugcc.ua), Римо-католицької церкви в Україні (http://www.rkc.lviv.ua/);

- Українського сегменту Вікіпедії (https:// uk.wikipedia.org/);

- Інтерактивні туристичні атласи та карти областей: Хмельниччини (https://turistmapa.com. ua), Тернопільщини (https://www.arcgis.com/), Житомирщини (http://tic.zt.ua/pro-zhytomyrshchynu/ mapa-oblasti);

- контенти та карти пам'яткознавчих та туристичних сайтів: «Пам'ятки України» (https:// zabytki.in.ua), «Мандруй Україною» (https://turson. at.ua/), «Пам'ятки України - Енциклопедія пам'яток» (http://encyclosights.com/), «Україна Інкогніта: Подорожі маловідомими та заповідними місцями» (http://ukrainaincognita.com/), Порталу «Дримба» (https://drymba.com/), Турпорталу «IGotoWorld» (https://ua.igotoworld.com/ua/) та інших.

Категорія культурної спадщини «Науковотехнічна спадщина" має свої витоки ще 3 1960-х рр., коли у Великій Британії було започатковано діяльність громадської організації жителів індустріальних центрів, яка виступила за збереження промислових об'єктів як культурних пам'яток і важливих елементів соціокультурного середовища проживання сучасного суспільства.
В 1976 р. було створено Міжнародний комітет із збереження промислової (індустріальної) спадщини (The International Committee for the Conservation of the Industrial Heritage (TICCIH)), який в своїй Нижньотагільскій хартії 2003 р. вперше означив, що промислова (індустріальна) спадщина включає в себе цінності індустріальної культури, які мають історичне, технологічне, соціальне, архітектурне або наукове значення.

3 тих пір проблема збереження промислової (індустріальної) визнана в усьому світі, чому

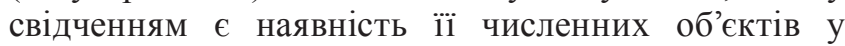
Списку Всесвітньої спадщини ЮНЕСКО. Крім того, у 2012 р. ЮНЕСКО започаткувало розроблення відповідного Глобального тематичного дослідження (з 2018 р. - ініціатива в області спадщини астрономії, науки і техніки).

Україна з 2007 р. представлена у Списку Всесвітньої спадщини ЮНЕСКО чотирма геодезичними пунктами транскордонного об'єкту «Дуга Струве» - «Баранівка», «Катеринівка», «Фельдштин» в Хмельницькій області, «Старонекрасівка» в Одеській області.

Об’єкт «Астрономічні обсерваторії України», у складі якого астрономічні обсерваторії Київського національного університету імені Тараса Шевченка та Одеського національного університету імені I. I. Мечникова, Кримська астрофізична обсерваторія у смт Наукове та смт Кацівелі та Миколаївська астрономічна обсерваторія, у 2008 p. визнано кандидатом на внесення до списку. Інший кандидат до списку - Будинок Державної промисловості у Харкові (Держпром), є пам'яткою архітектури та містобудування національного значення та номінується як видатний приклад конструкції, архітектурного або технологічного ансамблю, що ілюструє значущий період людської історії. Однак, зважаючи на образ цієї будівлі як символу «індустріального» Харкова або «індустріалізації країни» в цілому, який закладався при іiі проектуванні та спорудженні на початку 20 -ого ст., можна стверджувати, що він ілюструє певний період історії розвитку науки і техніки України та може розглядатися також як її пам'ятка.

До Міжнародного реєстру «Пам'ять світу», в якому представлені пам'ятки Всесвітньої документальної спадщини (документованої колективної пам'яті народів світу), у 2017 р. увійшов комплекс документів Національного архівного фонду України, пов'язаний з аварією на Чорнобильській АЕС.

У пам'яткоохоронному законодавстві України нерухомі об’єкти науки і техніки виділяються в окремий вид лише з 2004 р., як унікальні промислові, виробничі, науково-виробничі, інженерні, інженернотранспортні, видобувні об’єкти, що визначають рівень розвитку науки і техніки певної епохи, певних наукових напрямів або промислових галузей.

До цього часу об’єкти виробництва, науки і техніки було взято на облік лише як пам'ятки архітектури та містобудування або історії. Як зазначають пам'яткознавці, нерухомі пам'ятки 
цього профілю фіксують в більшості випадків лише «матеріальну оболонку» об'єктів, виступаючи, таким чином, найчастіше уречевленими віхами основних етапів історії науково-технічного прогресу. Дослідження вказаних об'єктів з точки зору історії виробництва і техніки практично не проводилось. Визначення основних напрямків виявлення та вивчення пам'яток історії виробництва і техніки має спиратися, передусім, на грунтовне дослідження провідних галузей економіки України, що історично склалися впродовж її багатовікової історії (Gavrilyuk et al., 2011).

В 2016 p. запроваджено Державний реєстр наукових об'єктів, що становлять національне надбання (фактично ведеться 32001 р.). Науковий об'єкт, що становить національне надбання - це унікальний об'єкт, що не піддається відтворенню, втрата або руйнування якого матиме серйозні негативні наслідки для розвитку науки та суспільства. До об’єктів можуть бути віднесені: унікальні об'єктимузейних, архівних фондів, колекції, особливо цінні та рідкісні видання, інші пам'ятки історії та культури; інформаційні фонди; дослідні установки, обладнання, полігони; природні та біосферні заповідники, національні природні парки, заказники, пам'ятки природи, ботанічні сади, дендрологічні парки, інші природні території та об'єкти, штучно створені об'єкти природно-заповідного фонду, або їх окремі частини, зокрема ботанічні, зоологічні, мікробіологічні та інші колекції; інші унікальні наукові об'єкти.

Значимим засобом захисту, інтерпретації та популяризації науково-технічної спадщини також виступають музеї.

Зазначені положення, підкріплені теоретичними та практичними працями вітчизняних науковців 3 питань виявлення, збереження, вивчення та популяризації пам'яток науки і техніки, серед яких Л. Гриффен, В. Ієвлєва, В. Казаков, В. Константинов, О. Корнієнко, В. Пацюк, Е. Титова, Ю. Тютюнник, М. Тямін та інших, обумовили загальні принципи та підходи до визначення терміну «Науково-технічна спадщина», ㄲï класифікації та відбору об'єктів картографування.

В Атласі під науково-технічної спадщиною розуміється сукупність матеріальних рухомих та нерухомих цінностей, пам'яток, об'єктів та територій культурної спадщини у їх взаємозв'язку та взаємозалежності 3 природною спадщиною, які пов'язані 3 виробничою i науково-технічною діяльністю суспільства, визначають рівень розвитку промисловості, науки і техніки певної епохи, мають історичне, архітектурне, технологічне, наукове, естетичне або соціальне значення та важливі для збереження, охорони та передачі наступним поколінням.

До складу підрозділу включено:

- карту «Промислова спадщуина», на якій відображені на окремих тематичних шарах пам'ятки промислової спадщини, структуровані за окремими галузями наступним чином: промислово-виробнича спадщина; гідротехнічна спадщина; інженерна та інженерно-транспортна спадщина; агропромислова спадщина (в т. ч.: вітряні, водяні та парові млини); музеї науково-технічного профілю (загальнотехнічні та галузеві) та історії промислових, транспортних та комунальних підприємств та установ;

- карту «Наукова спадщзина», на якій відображені пам'ятки наукової спадщини, наукові об'єкти, що становлять національне надбання та музеї історії наукових установ та освітніх закладів.

Завершальним в Атласі $\epsilon$ важливий блок 38 карт «Охорона, збереження, відновлення та використання природної та культурної спадцини», спрямованих на висвітлення особливостей державного управління у цій сфері.

До складу підрозділу «Заходи 3 охорони природної спадщзни» увійшли карти:

- «Розвиток системи природно-заповідного фонду», в якій відображені показники збільшення частки площ ПЗФ до площ адміністративних одиниць за 1995-2019 pр. та питома вага площ ПЗФ до площ адміністративних одиниць (\%, рік);

- «Види рослин та тварин, занесені до Червоної книги України», в якій відображені показники чисельності видів рослин і тварин, занесених до Червоної книги України та їх охоронний статус (зникаючі та зниклі; вразливі рідкісні; недостатньо відомі та неоцінені).

Підрозділ «Заходи $з$ охорони культурної спадщиини» містить карти:

- «Правові, організаиійні, науково-дослідні mа інші заходи», яка конкретизує заходи з охорони культурної спадщини за регіонами, а саме: пам'ятки, навколо яких установлено зони охорони; комплекси (ансамблі), навколо яких установлено зони охорони; історичні населені місця, що мають затверджені межі історичних ареалів та режими використання їх територій; укладені охоронні договори; оформлені паспорти об'єктів (пам'яток) культурної спадщини; пам'ятки, що пройшли інвентаризацію;

«Ремонтно-реставраційні роботи на пам'ятках культурної спадщини», на якій відображені показники кількості пам'яток, на яких завершено ремонтно-реставраційні роботи та обсяги фінансування ремонтно-реставраційних робіт на пам'ятках та інших заходів 3 охорони культурної спадщини та джерела їх фінансування.

До підрозділу «Розвиток форм збереження та популяризації культурної спадщцини» увійшли наступні карти, які характеризують форми (інституції) збереження культурних цінностей, їх актуалізації, популяризації і трансляції наступним поколінням найціннішої частини культурної i природної спадщини - музеї, бібліотеки, архіви:

- «Музеї». За даними Державної служби статистики України музейна сфера у 2017 р. нараховувала 574 музеї (у 2013 р. -608), за статусом 3 них 48 (50) - національні, 22 (26) - державні, 504 (532) - обласні, районні, міські та інші. Крім того, за даними за 2013 р. також до музейної сфери належать 3507 музеїв, які не підлягають державній реєстрації та створені у складі підприємств, установ, організацій, навчальних закладів. Музеї 
представлені за їх спеціалізацією (історичні, археологічні, краєзнавчі, природничі, літературні, мистецькі, етнографічні, інші), охарактеризовані за формою (музеї, будинки-музеї, музеї-квартири, кабінети-музеї, музеї-садиби, музеї-заповідники, музеї під відкритим небом тощо) та формою власності (державної або приватної);

- «Бібліотеки». Характеризує стан бібліотечної мережі у міських та сільських поселеннях та наявний бібліотечний фонд;

- «Установи галузі культури», яка відображає основні показники обсягів діяльності 3 обслуговування населення та надання культурних послуг. На ній відображена спеціалізація установ культури та наведені аналітичні індекси ресурсного потенціалу сфери культури і мистецтва за 2017 р.).

На жаль, недостатнє бюджетне фінансування розроблення Атласу ПіКС, що мало місце в окремі роки, не дало змогу реалізувати певну частину задуманого. На сьогодні велика кількість потенційних сюжетів карт ще заходиться в роботі, має часткове концептуальне, методичне і картографічне опрацювання та достатню забезпеченість вихідними матеріалами. Тематика частини карт є продовженням картографування категорій спадщини, які не мають офіційно встановленого статусу - зокрема, «Культурно-ландшафтної спадщини України».

Законодавче визнання культурного ландшафту як особливого типу культурної та природної спадщини та активна динаміка впровадження культурноландшафтного підходу до охорони всесвітньої спадщини у міжнародному праві спостерігається 3 1992 року після включення цієї дефініції в Керівні настанови до реалізації Конвенції ВКПС. Зазначені Керівні настанови визначили культурні ландшафти як об'єкти культурної спадщини, що представляють собою спільні творіння людини i природи, які ілюструють еволюцію людської спільноти і поселень 3 плином часу, що відбувалася під впливом фізичних обмежень i/aбо можливостей, що накладаються або надаються природним місцем існування людини, a також соціальних, економічних i культурних чинників, що змінюють один одного, як зовнішніх, так і внутрішніх (UNESCO, 2019).

Включення культурних ландшафтів, як окремої номінації до Списку всесвітньої спадщини, та їх інтенсивно зростаюча кількість (станом на кінець 2021 року номінація включала 119 об’єктів з 65 держав або 10 відсотків від загальної кількості об'єктів Списку), засвідчили про велику зацікавленість урядів, широкої громадськості та місцевих спільнот до збереження культурної та природної спадщини на засадах їх взаємозв'язку та взаємодії та застосування культурного ландшафту як однією з кращих форм збереження спадщини.

У чинному законодавстві України відсутній термін «культурний ландшафт», прийнятий у Конвенції ВКПС. Натомість, з 2000 року в окремий вид культурної спадщини виділяються «ландшафтні об’єкти», під якими розуміються природні території, які мають історичну цінність, однак, 3 тих пір до Державного реєстру нерухомих пам'яток України внесені лише 7 ландшафтних об'єктів, які є об'єктом охорони як окреме територіальне утворення.

Загалом це неприпустимо мало, проте при цьому слід зважати на наявність на державному обліку ще понад 320 пам'яток садово-паркового мистецтва, які можуть бути віднесені до категорії культурних ландшафтів, оскільки характеризуються поєднанням паркового будівництва 3 природними або створеними людиною ландшафтами. Крім того, збереження ландшафтів та інших природних комплексів, унікальних територій та природних об'єктів, пов'язаних 3 історико-культурною спадщиною $\epsilon$ одним із завдань законодавства про охорону навколишнього природного середовища. Основними формами правової охорони і регулювання використання ландшафтів виступають паркипам'ятки садово-паркового мистецтва, регіональні ландшафтні парки, ландшафтні заказники, дендрологічні парки.

В той же час, Україна, попри величезний історико-культурний та природний потенціал, в Списку всесвітньої спадщини представлена лише одним культурним ландшафтом - стародавнім містом Херсонесом Таврійським і його Хорою (2013).

Суттєве відставання України у застосуванні культурно-ландшафтного підходу та відсутність цілісної картини культурно-ландшафтної спадщини країни 3 відображенням iї сучасного стану та геопросторових закономірностей формування обумовлює такі завдання перспективних досліджень, як удосконалення понятійного апарату, всебічне вивчення структурних компонентів культурноландшафтної спадщини, їх систематизація та класифікація, створення комплексної інформаційноаналітичної бази культурних ландшафтів із застосуванням апарату геоінформаційних технологій 3 метою подальшого електронного картографування.

При цьому під культурним ландшафтом розуміється природно-культурне локальне територіальне утворення, яке $\epsilon$ результатом історичної та сучасної взаємодії даного суспільства і природного середовища, та цілісний образ якого сприймається i цінується за іiі природні та культурні якості (матеріальні та духовні) унікального (всесвітнього), видатного (національного) чи великого (місцевого) значення. Сукупність культурних ландшафтів, охоплених існуючими територіальними організаційно-правовими формами та механізмами охорони природної і культурної спадщини на міжнародному, національному та місцевому рівнях, складає культурно-ландшафтну спадщину України.

Розгляд об'єктів, які охороняються згідно пам'яткоохоронного або природоохоронного законодавства України та підпадають під критерії визначення як культурного ландшафту, свідчить про їх велике типологічне різноманіття. В першому приближенні серед більш ніж 1000 об’єктів можна виділити такі їх види, як:

- садово-паркові (в т.ч.: палацово-паркові та садибно-паркові; меморіальні; науково-освітні; курортно-рекреаційні; міські; сільські);

- історико-культурні та історико-археологічні; 
- військово-історичні;

- замкові та фортифікаційні;

- сакральні (в т.ч.: джерела, скелі, гори, долини, печери та печерні храми);

- етнокультурні (в т.ч.: етнографічні музеї заповідники та середовищні музеї: музеї народної архітектури та побуту просто неба, музеї-хати (садиби), етнографічні та історико-культурні комплекси):

- індустріальні (в т.Ч.: промислово-виробничі, інженерно-технічні та науково-технічні).

Картографічна візуалізація просторової та детальної атрибутивної, в тому числі, мультимедійної) інформації про ці об'єкти також може стати предметом для створення низки інтерактивних картографічних сюжетів та подальшого їх об'єднання в окрему тематичну збірку.

Діяльність Інституту географії НАН України, спрямовану на формування інфраструктури геопросторових даних про природу, населення та культурну спадщину України, що знайшло відображення, зокрема, в Атласі ПіКС, була розглянута та схвалена Президією НАН України. При цьому відзначено, що значимість розробки полягає у використанні Атласу ПіКС як ресурсу для інформаційної підтримки планування збалансованого регіонального та державного розвитку в напрямі гуманізації суспільства, який сприятиме якісній законодавчій діяльності у сфері національної спадщини, розробленню та вдосконаленню нормативних i регламентуючих документів різного типу, змісту та призначення відповідно до вже ратифікованих Україною міжнародних конвенцій стосовно охорони культурної і природної спадщини. Атлас буде джерелом знань для населення, допомагатиме методологічному та інформаційному наповненню предметної сфери суспільних і природничих наук.

Рішенням Президії НАН України від 3 лютого 2021 року №28 було доручено розробникам Атласу ПіКС оформити авторські права на нього, здійснити тиражування на дисках для розповсюдження в управлінських структурах держави i серед населення та підготувати його паперову версію (Rudenko, 2021). Колектив розробників у квітні 2021 року зареєстрував авторське право на електронний атлас, однак питання фінансового забезпечення інших поставлених Президією НАН України завдань в складних умовах поточного року не було вирішено, що відтерміновує їх виконання на початок 2022 року.

\section{Висновки i перспективи подальших} досліджень. Створення першого в Україні електронного Атласу ПіКС, розроблення якого здійснював Інститут географії НАНУ протягом останніх років, засвідчило про перехід до нового етапу розвитку вітчизняного тематичного картографування збереження національної спадщини.

Застосування сучасних геоінформаційних, мультимедійних та інтерактивних технологій створили широкий спектр нових можливостей для атласного картографування та, як наслідок, обумовили перехід до розроблення електронних атласів та атласних інформаційних систем, для яких характерні модульність та безперервність розвитку, еволюційність i динамічність, сумісність, мультимасштабність, мультимедійність та універсальність.

Робота зі створення атласу, що полягала в картографуванні значної кількості об’єктів та територій ПіКС різних видів, типів та категорій на базі створеної атласної геоінформаційної системи, трансформувалась у складний i багатогранний процес, який базувався на комплексі теоретичних, методологічних та методичних підходів 3 різних сфер пізнання цього важливого суспільного явища.

Необхідність врахування сучасних світових тенденцій, пов'язаних 3 появою нових та розвитку існуючих складових ПіКС, в умовах відсутності у вітчизняному природоохоронному та пам'яткоохоронному законодавстві багатьох загальноприйнятих у міжнародному праві та науковому середовищі понять та термінів, обумовили розроблення оригінальних тематичних карт етнокультурної, релігійної і науково-технічної спадщини, що становить наукову новизну Атласу. Ці перші в Україні спеціалізовані карти подібної тематики та масштабу охоплення дозволяють значно розширити предметне поле досліджень ПіКС та можуть сприяти введенню у наукову практику нових категорій спадщини.

Як підсумок, карти блоку «Природна і культурна спадщина» Атласу являють собою звід сучасної просторової інформації та знань про особливості розміщення об'єктів і територій спадщини України, стимулюють розвиток теорії та методів тематичного та атласного картографування, слугуватимуть науковою та інформаційною підтримкою у розробленні загальнодержавних та регіональних програм і проектів в галузі вивчення, охорони та комплексного використання спадщини та включенні цієї проблематики до стратегій сталого розвитку та соціально-економічного розвитку держави, регіонів, районів та міст.

Перспективи подальшого розвитку атласного електронного картографування ПіКС можуть бути пов'язані з виконанням наступних завдань:

- поглибленням регіонального аспекту тематичних досліджень та створенням комплексних електронних атласів ПіКС географічних або історико-географічних регіонів (Карпати, Крим, Полісся, Поділля, Слобожанщина тощо), областей та окремих міст (Київ, Львів тощо);

- поглибленням тематичних досліджень за окремими комплексними категоріями предметного вивчення спадщини та створенням відповідних електронних атласів - культурно-ландшафтної, архітектурно-ландшафтної, етнокультурної, релігійної, науково-технічної, воєнно- та військовоісторичної, археологічної, морської та річкової, мистецької спадщини України та окремих iï територій. 


\section{References:}

Council of Europe (2019). Updated list of officially adopted Emerald sites. Convention on the Conservation of European Wildlife and Natural Habitats. Standing Committee. 39th meeting. Strasbourg, 3-6 December 2019. Retrieved from: https://rm.coe.int/updated-list-of-officially-adopted-emerald-sites-december-2019-/168098ef51

Fedorova, L. D. (2015). Historical monuments in the general system of cultural heritage. In Cultural heritage in the context of the "Collection of monuments of history and culture of Ukraine" (pp. 193-194). Kyiv: Institute of History of Ukraine of NASU. [In Ukrainian] [Федорова Л.Д. Пам'ятки історії у загальній системі культурної спадщини/Культурна спадщина в контексті «Зводу пам'яток історії та культури України». Київ: Інститут історії України, 2015. С. 193-194.]

Gavrilyuk, L. O., Gorbyk, V. O., Denisenko, G. G., Kot, S. I., Piskova, E. M., Skripnik, P. I., \& Fedorova, L. D. (2011). Theoretical and scientific-methodical principles of preparation of articles about historical monuments to "Collection of Monuments of History and Culture of Ukraine". Kyiv: Institute of History of Ukraine of NASU. [In Ukrainian] [Теоретичні та науково-методичні засади підготовки статей про пам'ятки історії до «Зводу пам'яток історії та культури України». Київ: Інститут історії України НАН України, 2011. 272 с.]

Kalinin, V. I. \& Gurskiy, D. S. (Eds.). (2006-2011). Geological landmarks of Ukraine (in 4 volumes). Kyiv-Lviv: State Geological Survey of Ukraine, Ukrainian State Geological Survey Institute. [In Ukrainian] [Геологічні пам’ятки України у 4 томах / За ред. В. І. Калініна, Д.С. Гурського (2006-2011). Державна геологічна служба України, Український державний геологорозвідувальний інститут, Київ-Львів.]

Polyvach, K. A. (2005). Mapping of Ukraine historical and cultural heritage. Ukrainian geographical journal, 3, 60-66. [In Ukrainian]. [Поливач К.А. Картографування історико-культурної спадщини в Україні. Український географічний журнал. 2005. №3. С. 60 - 66.]

Polyvach, K. A. (2007). Cultural and natural heritage. In Rudenko, L. H. (Ed.). The National Atlas of Ukraine (p. 53). Kyiv: SSPE Cartografia. [In Ukrainian]. [Національний атлас України / Гол. ред. Л.Г.Руденко. К.: ДНВП «Картографія», 2007. С.53.]

Polyvach, K. A. (2012). Cultural heritage and its influence on the development of regions of Ukraine. Kyiv: Institute of Geography of NASU. [In Ukrainian]. [Поливач К. А. Культурна спадщина та іiі вплив на розвиток регіонів України. Київ, 2012. 208 с.]

Polyvach, K. A. (2016). Information and reference atlas of the nature reserve fund of the region. Ukrainian geographical journal, 1, 53-60. Doi: 10.15407/ugz2016.1.053. [In Ukrainian]. [Поливач К.А. Інформаційнодовідковий атлас природно-заповідного фонду регіону. Український географічний журнал. 2016. №1. С. $53-$ 60. Doi: 10.15407/ugz2016.1.053]

Polyvach, K. A. (2018). Preconditions, purpose and tasks of the Atlas geoinformation system of cultural heritage of Ukraine. In Rudenko, L.H. (Ed.). Cultural heritage in the Atlas geoinformation system of sustainable development of Ukraine (pp. 68-73). Kyiv. [In Ukrainian]. [Поливач К.А. Передумови, мета і завдання Атласної геоінформаційної системи культурної спадщини України. Культурна спадщина в Атласній геоінформаційній системі сталого розвитку України / за ред. Л.Г. Руденка. Київ, 2018. С. 68-73.]

Rudenko, L. H. (2021). Atlas "Population of Ukraine and its natural and cultural heritage". Transcript of the report at the meeting of the Presidium of the NAS of Ukraine on February 3, 2021. Visnyk of the National Academy of Sciences of Ukraine, 3, 12-13. Doi: 10.15407/visn2021.03.029 [In Ukrainian]. [Руденко Л.Г. Атлас «Населення України та його природна і культурна спадщина». Стенограма доповіді на засіданні Президії НАН України 3 лютого 2021 року. Вісник Національної академії наук України 2021. №3. С. 12-13. Doi: 10.15407/visn2021.03.029].

Rudenko, L. H \& Polyvach, K. A. (2015). Natural heritage: experience and prospects of mapping in Ukraine. Ukrainian Geographical Journal, 4, 40-49. Doi: 10.15407/ugz2015.04.040 [In Ukrainian]. [Руденко Л. Г., Поливач К.А. Природна спадщина: досвід та перспективи картографування в Україні. Украӥнський географічний журнал. 2015. №4. C.40-49. Doi: 10.15407/ugz2015.04.040]

Rudenko, L. H. (Ed.) (2021). Academic geography and atlas mapping during the years of Ukraine's independence (pp. 31-108). Kyiv: Institute of Geography of NASU. [In Ukrainian] [Академічна географія і атласне картографування за роки незалежності України /За ред. Л. Г. Руденка. Ін-т географії НАН України, 2021. C. 31-108.]

Rystedt, B. (1995). Current trends in electronic atlas production. Cartographic Perspectives, 20, 5-11. Doi: 10.14714/ CP20.889

Skrypnyk, G. (Ed.). (2011). History of Decorative Art of Ukraine. Vol. 4. Kyiv: Institute for Art Studies, Folklore and Ethnology of NASU. [In Ukrainian] [Історія декоративного мистецтва України: у 5 т. / IMФЕ ім. М.T. Рильського НАН України; гол. ред. Г. Скрипник; Т. 4: Народне мистецтво та художні промисли ХХ ст. Київ, 2011. $512 \mathrm{c}$.]

Topornytska, M. Ya. (2015). Territorial organization of ethnic festival tourism in Lviv region. (PhD dissertation). Lviv. [In Ukrainian]. [Топорницька М.Я. Територіальна організація етнофестивального туризму Львівської області: дис. ... канд. геогр. наук: 11.00 .02 - економічна та соціальна географія. / Львівський національний університет імені Івана Франка, Львів, 2015. 253 с.].

UNESCO (1972). Recommendation on the protection of cultural and natural heritage at the national level. Retrieved from: http://zakon4.rada.gov.ua/laws/show/995_724 [In Ukrainian]. [Рекомендація про охорону на 
національному рівні культурної та природної спадщини. URL: http://zakon4.rada.gov.ua/laws/show/995_724 ]

UNESCO (2012). World Heritage Atlas. Paris: UNESCO Publishing; Novara, Italy: De Agostini Libri.

UNESCO (2019). Operational Guidelines for the Implementation of the World Heritage Convention WHC.19/01 10 July 2019. Retrieved from: https://whc.unesco.org/document/178167

UNESCO (2020). World Heritage Centre - Initiative on Heritage of Religious Interest. Retrieved from: https://whc.unesco.org/en/religious-sacred-heritage

Vedenin, Yu. A. \& Kuleshova, M. E. (Eds.). (2004). Cultural Landscape As A Heritage Site. (p. 10). Moskva: Russian Research Heritage Institute; St. Petersburg: Dmitry Bulanin. [in Russian] [Культурный ландшафт как объект наследия / под ред. Ю.А. Веденина, М.Е. Кулешовой. Москва: Институт Наследия; СПб.: Дмитрий Буланин, 2004.].

Wikimedia Commons (2021). Monuments database/ Statistics. Retrieved from https://commons.wikimedia.org/ wiki/Commons:Monuments database/Statistics

Wimbledon, V. A. P., Gerasimenko, N. P., \& Ischenko, A. A. et al. (1999). Problems of the Ukraine geological heritage protection. Kyiv: DNU MFN of NAS of Ukraine. [in Ukrainian]. [Проблеми охорони геологічної спадщини України / В.А.П. Уїмблдон, Н.П. Герасименко, А.А. Іщенко та ін. К.: ДНУ РНС НАН України, 1999. 129 с.] 